\title{
GLP-1 improves palmitate-induced insulin resistance in human skeletal muscle via SIRT1 activity
}

\author{
JA YOUNG JEON ${ }^{1}$, SUNG-E CHOI ${ }^{2}$, EUN SUK HA ${ }^{1}$, HAN BYEOL LEE ${ }^{1}$, TAE HO KIM ${ }^{3}$, \\ SEUNG JIN HAN ${ }^{1}$, HAE JIN KIM ${ }^{1}$, DAE JUNG KIM ${ }^{1}$, YUP KANG ${ }^{2}$ and KWAN-WOO LEE \\ Departments of ${ }^{1}$ Endocrinology and Metabolism, and ${ }^{2}$ Physiology, \\ Ajou University School of Medicine, Suwon 16499; ${ }^{3}$ Division of Endocrinology and Metabolism, \\ Department of Internal Medicine, Seoul Medical Center, Seoul 02076, Republic of Korea
}

Received November 8, 2018; Accepted July 1, 2019

DOI: $10.3892 /$ ijmm.2019.4272

\begin{abstract}
The present study investigated whether glucagon like peptide-1 (GLP-1) improves glucose uptake through glucose transporter type 4 (GLUT4), mediated by the activation of sirtuin 1 (SIRT1), in skeletal muscle cells with palmitate induced-insulin resistance. The levels of glucose uptake, GLUT4, protein kinase A (PKA), and cyclic adenosine monophosphate (cAMP) were determined in human skeletal muscle myotubes (HSMMs) exposed to palmitate and GLP-1. Then, to determine whether PKA/cAMP were downstream signals of GLP-1, a PKA inhibitor was used. To determine whether SIRT-1 contributes to GLP-1 action in HSMMs with palmitate-induced insulin resistance, the levels of peroxisome proliferator-activated receptor $\gamma$ coactivator $1 \alpha(\mathrm{PGCl} 1 \alpha)$ deacetylation and SIRT-1 activity were assessed using a SIRT1 inhibitor and small interfering RNA (siRNA). The phosphorylation levels of protein kinase B (Akt) and insulin receptor substrate 1 (IRS-1) as insulin signaling pathways, were assessed in GLP-1-treated HSMMs exposed to palmitate. The influence of SIRT1 on the GLP-1-induced activation of insulin signaling pathway was determined using a SIRT1 inhibitor. GLP-1 restored the palmitate-induced reductions in the levels of glucose uptake, GLUT4 mRNA, GLUT4 promoter activity, and GLUT4 protein in HSMMs. PKA and cAMP, as GLP-1 downstream signals, played a role in this process. GLP-1 increased the deacetylation levels of PGC1 $\alpha$, and stimulated SIRT1 in HSMMs. Moreover, the SIRT1 inhibitor and siRNA of SIRT1 suppressed the effect of GLP-1 on GLUT4 expression in HSMMs exposed to palmitate. The SIRT1 inhibitor also prevented the GLP-1-induced phosphorylation of IRS-1
\end{abstract}

Correspondence to: Dr Kwan-Woo Lee, Department of Endocrinology and Metabolism, Ajou University School of Medicine, 164 World Cup-ro, Yeongtong-gu, Suwon 16499, Republic of Korea

E-mail:1kw65@ajou.ac.kr

Key words: glucagon like peptide1, glucose transporter type 4, sirtuin 1, insulin resistance, skeletal muscle and Akt in palmitate-treated HSMMs. The present findings suggest that in palmitate-induced insulin-resistant HSMM, GLP-1 activates SIRT1 through the PKA/cAMP pathway, which in turn enhances glucose uptake through GLUT4 and the insulin signaling pathway.

\section{Introduction}

Insulin resistance is a major pathogenic factor underlying the development of type 2 diabetes mellitus (T2DM) and obesity (1). Elevated concentrations of nonesterified fatty acids, particularly saturated fatty acids, play a critical role in the induction of insulin resistance (2). This is because saturated fatty acids impair insulin signaling via multiple mechanisms including increases in the activity of stress signaling kinases [(mitogen-activated protein kinase 8 (JNK), inhibitor of nuclear factor- $\mathrm{\kappa B}$ kinase (IKK), and protein kinase B (PKC)], enhanced levels of reactive oxygen species, activation of endoplasmic reticulum stress, perturbations in mitochondrial function, and the accumulation of lipid intermediates (3-5). Due to impairments in insulin signaling, $\mathrm{C} 2$ myotubes and human skeletal muscle exposed to saturated fatty acids, such as palmitate exhibit a failure of the glucose transporter type 4 (GLUT4) to translocate from the cytosol to the membrane due to impairments in insulin signaling $(6,7)$.

Glucagon-like peptide-1 (GLP-1) is a hormone secreted from intestinal L-cells in response to nutrients and exerts glucose-dependent insulinotropic actions in pancreatic islet cells (8). Additionally, GLP-1 has extra-pancreatic effects that include the generation of increased glucose uptake and the regulation of energy homeostasis in the skeletal muscles of rats and obese humans through the activation of the phosphoinositide 3 kinase (PI3K)/protein kinase B (Akt) and mitogen-activated protein kinase pathways (9). Muscle-specific GLP-1-overexpressing transgenic mice exhibit reduced weight gain and improved lipid profiles following a high-fat diet challenge (10), and GLP-1 upregulates the translocation and expression of GLUT4 in the heart and skeletal muscles of spontaneously hypertensive rats (11).

Sirtuin 1 (SIRT1), a mammalian ortholog of Sir2, is an NAD-dependent protein deacetylase that is thought to play a critical role in the adaptation of cells to metabolic alterations 
during insulin resistance. The whole-body overexpression of SIRT1 prevents the development of metabolic disorders in mice fed a high-fat diet (12), and the pharmacological activation of SIRT1 increases insulin sensitivity in skeletal muscle in animal models of insulin resistance (13). Forskolin, epinephrine, and oleic acid stimulate the cyclic adenosine monophosphate (cAMP) and protein kinase A (PKA) pathway to activate SIRT1 activity, which in turn increases the rate of fatty acid oxidation in skeletal muscle cells $(14,15)$. Exenatide, a GLP-1 agonist, activates the cAMP/PKA pathway and ameliorates hepatic steatosis via SIRT1 activation in obese C57BL/6J mice fed a high-fat diet (16). This result is consistent with investigations of the GLP-1 receptor agonist Exendin-4, which activates the cAMP/PKA pathway, reduces endoplasmic reticulum stress, and leads to attenuation of hepatic steatohepatitis in high-fat diet-induced obese C57BL/6J mice in a SIRT1-dependent manner (17,18). However, GLP-1 also inhibits SIRT1-related deacetylase activity during the mass expansion of pancreatic $\beta$-cells (19). Regardless of the direction, it is evident that there is a link between the activities of GLP-1 and SIRT1.

The relationship between GLP-1 and SIRT1 and the effects of GLP-1 on palmitate-induced insulin resistance and GLUT4 regulation in human skeletal muscle remain poorly understood. Thus, the present study investigated whether GLP-1 has a protective effect on human skeletal muscle myotubes (HSMMs) exhibiting palmitate-induced insulin resistance. Moreover, the present study investigated whether the effects of GLP-1 occur through SIRT1 activation.

\section{Materials and methods}

Reagents. The present study utilized recombinant human GLP-1 (ProSpec; Ness Ziona), the SIRT-1 inhibitor EX527 (cat. no. E-7034; Sigma-Aldrich; Merck KGaA), BSA (cat. no. A9418; Sigma-Aldrich; Merck KGaA), palmitate (cat. no. P5586; Sigma-Aldrich; Merck KGaA), H-89 dihydrochloride (cat. no. 127243-85-0; Merck KGaA) and insulin (cat. no. 19278; Sigma-Aldrich; Merck KGaA), all of which were dissolved in the appropriate medium or PBS prior to use at the required working dilution. Recombinant GLP-1 is an active form of native GLP-1. It consists of 30 amino acids and has a half-life of $<2$ min, due to its degradation by the DPPIV enzyme in the circulation. The palmitate/BSA conjugates were prepared as described previously (20) and used to treat the cultured cells. Briefly, a 20-mM solution of palmitate in $0.01 \mathrm{M} \mathrm{NaOH}$ was incubated for $30 \mathrm{~min}$ at $70^{\circ} \mathrm{C}$, and then fatty acid soaps were mixed with 5\% BSA in PBS at an 8:1 molar ratio.

Cell cultures. The present study used normal HSMMs (Lonza Group, Ltd.). The undifferentiated myoblasts were cultured using a Bulletkit containing basal medium (SkBM; cat. no. CC3161; Lonza Group, Ltd.) at $37^{\circ} \mathrm{C}$ in an atmosphere of $5 \% \mathrm{CO}_{2}$. The cells were then induced to differentiate using DMEM (Gibco; Thermo Fisher Scientific, Inc.; cat. no. 11500416) supplemented with $2 \%$ horse serum (Gibco; Thermo Fisher Scientific, Inc.; cat. no. 10368902), 2 mmol/l glutamine, and $50 \mathrm{U} / \mathrm{ml}$ streptomycin and penicillin; the medium was replaced every other day. The normal HSMMs were grown for 6 days prior to harvesting for either the protein or RNA analyses. The differentiated HSMMs were either treated with palmitate $(200 \mu \mathrm{mol} / \mathrm{l})$ or stimulated with recombinant GLP-1 (100 or $200 \mathrm{nmol} / \mathrm{l})$ for $24 \mathrm{~h}$. Cell viability and cytotoxicity under palmitate treatment (100 or $200 \mu \mathrm{mol} / \mathrm{l})$ were measured using 2-(2-methoxy-4-nitrophenyl)-3-(4-nitr ophenyl)-5-(2,4-disulfophenyl)-2 H tetrazolium monosodium salt (Cell Counting Kit-8; CCK-8) assay (Sigma-Aldrich; Merck KGaA). Briefly, differentiated HSMMs treated with 100 or $200 \mu \mathrm{M}$ palmitate were cultured in a 96-well tissue culture plate. After $24 \mathrm{~h}, 10 \mu \mathrm{l}$ CCK-8 solution was added to each well and the cells were incubated for another $4 \mathrm{~h}$ at $37^{\circ} \mathrm{C}$. Relative cell viability was determined by scanning with an ELISA reader with a $450 \mathrm{~nm}$ filter and calculated based on a CCK-8 assay.

Uptake of 2-NBDG by HSMMs. The HSMMs were treated with either palmitate $(200 \mu \mathrm{M})$ or GLP-1 (200 nmol/l) for $24 \mathrm{~h}$. The cells then were starved for $16 \mathrm{~h}$ and pre-incubated in Krebs-Ringer bicarbonate buffer ( $\mathrm{pH}$ 7.4) containing $2 \%$ BSA for $30 \mathrm{~min}$ at $37^{\circ} \mathrm{C}$. Next, the HSMMs were treated with $500 \mu \mathrm{mol} / 12$-N-(7-nitrobenz-2-oxa-1,3-diazol-4-yl) amino-2-deoxyglucose (2-NBDG; cat. no. N13195; Invitrogen; Thermo Fisher Scientific, Inc.) in either the presence or absence of insulin $(100 \mathrm{nmol} / \mathrm{l})$ for $3 \mathrm{~h}$ at $37^{\circ} \mathrm{C}$. The cells were then rinsed three times with ice-cold PBS, lysed with RIPA Lysis and Extraction buffer (cat. no. 89900; Thermo Fisher Scientific, Inc.), and the lysates were centrifuged at $12,000 \mathrm{x} \mathrm{g}$ for $30 \mathrm{~min}$ at $4^{\circ} \mathrm{C}$. The supernatants were measured for fluorescence (excitation: $475 \mathrm{~nm}$; emission: $550 \mathrm{~nm}$ ) using a SpectraMax Gemini EM microplate reader (Molecular Devices, LLC). The protein concentrations were determined using the Bradford assay (Coomassie Protein Reagent, Pierce; Thermo Fisher Scientific, Inc.).

Semiquantitative reverse transcription-PCR (RT-PCR) analysis. The mRNA expression levels were compared using semi-quantitative RT-PCR performed after RNA extraction using the TRIzol ${ }^{\circledR}$ method (Invitrogen; Thermo Fisher Scientific, Inc.). cDNA was synthesized by RT-PCR using the Takara RNA PCR kit (AMV) ver 3. supplied by Takara Bio, Inc. The first strand cDNA was synthesized from $1 \mathrm{~g}$ total RNA using the AMV reverse transcriptase and the random 9-mer oligo-nucleotide. The RT reaction was performed for 1 cycle under the condition of $30^{\circ} \mathrm{C}$ for $10 \mathrm{~min}, 42^{\circ} \mathrm{C}$ for $30 \mathrm{~min}, 95^{\circ} \mathrm{C}$ for $5 \mathrm{~min}$ and $5^{\circ} \mathrm{C}$ for $5 \mathrm{~min}$. Then the PCR reaction was performed using a Takara Shuzo PCR Amplification kit (cat. no. R011; Takara Bio, Inc.) with primer sets specific for different genes. The following PCR primers were used in the present study: GLUT4, 5'-TGGCTGAGCTGAAGGATGAG-3' and 5'-CCAACAACACCGAGACCAAG-3'; and GAPDH, 5'-GGTGAAGGTCGGAGTCAACG-3' and 5'-CAAAGTTGT CATGGATGACC-3'. The thermal conditions for the GLUT4, and GAPDH were denaturation for $30 \mathrm{sec}$ at $95^{\circ} \mathrm{C}$, annealing for $30 \mathrm{sec}$ at $56^{\circ} \mathrm{C}$, and extension for $30 \mathrm{sec}$ at $72^{\circ} \mathrm{C}$. The amplifications of the GLUT4, and GAPDH were performed using 35, and 25-28 cycles, respectively. The amplified PCR products were separated by electrophoresis on a $1.5 \%$ agarose gel. Then gel was stained with ethidium bromide for $30 \mathrm{~min}$ at room temperature and washed with distilled water for $10 \mathrm{~min}$. The levels of amplified cDNA were quantified by 
densitometric analysis [Quantity One-4.6.9 (basic) analysis software; Bio-Rad Laboratories, Inc.] of the stained bands and compared with those of GAPDH.

GLUT4 promoter activity. The HSMMs $\left(5 \times 10^{6}\right)$ were transfected with a reporter plasmid (mouse GLUT4 promoter luciferase reporter) using a pipette-type electroporator (Microporator-Mini; Digital Biotechnology) according to the manufacturer's protocol. The total transfected DNA amount was held constant at $50 \mathrm{ng}$ by the addition of the plasmid vector $\beta$-galactosidase ( $\beta$-gal). For the co-transfection of hG4-luc and $\beta$-gal, 5x10 ${ }^{6}$ HSMMs were mixed with 800 ng mouse GLUT4 promoter luciferase reporter, as previously described (6) and $50 \mathrm{ng} \beta$-gal in $100 \mu \mathrm{l} \mathrm{R}$ buffer by microporation at $1,380 \mathrm{~V}$ and $30 \mathrm{~m}$ width. Following transfection, the HSMMs were induced to differentiate by switching to a differentiation medium for $48 \mathrm{~h}$. Following differentiation, the cells were treated either with or without palmitate and/or GLP-1 for $24 \mathrm{~h}$, and the cell lysates were prepared by adding lysis buffer and then scraping, vortexing, and centrifuging $\left(12,000 \mathrm{x} \mathrm{g}\right.$ for $2 \mathrm{~min}$ at $\left.4^{\circ} \mathrm{C}\right)$ the solution. For all lysates, $\beta$-gal activity was measured using $\beta$-Galactosidase Enzyme Assay System with Reporter Lysis Buffer (cat. no. E2000; Promega Corporation), and promoter activity was measured using a Luciferase Assay system (Promega Corporation) and TD-20/20 luminometer (Turner Design; Promega Corporation). Promoter activity was normalized to $\beta$-gal activity and the protein amount, and luciferase activity was determined by mixing $100 \mu$ l luciferase assay reagent with $20 \mu 1$ lysate and measuring the luminescence.

ELISA for $c A M P$. cAMP levels in the cell lysates were evaluated using the Direct cAMP ELISA kit (Enzo Life Sciences, Inc.; cat. no. BML-AK255) according to the manufacturer's protocol. The maximum intensity of the bands was converted to $100 \%$ and used to calculate the relative intensity.

Peroxisome proliferator-activated receptor $\gamma$ coactivator $1 \alpha(P G C 1 \alpha)$ acetylation. To assess the acetylation levels of PGC1 $\alpha$, the HSMMs were transfected using Lipofectamine ${ }^{\circledR}$ 2000 (cat. no. 11668027; Invitrogen; Thermo Fisher Scientific, Inc.) with $3 \mu \mathrm{g}$ pcDNA3 Flag-PGC1 $\alpha$ expression vector. The transfected cells were treated either with or without recombinant GLP-1 for $24 \mathrm{~h}$, and the acetylation status was determined by immunoprecipitating $1 \mathrm{mg}$ protein lysate in a RIPA lysis buffer [20 mmol/1 Tris (pH 8.0), $137 \mathrm{mmol} / \mathrm{l} \mathrm{NaCl}, 1 \mathrm{mmol} / \mathrm{l}$ $\mathrm{MgCl}_{2}, 2 \mathrm{mmol} / 1 \mathrm{CaCl}_{2}, 1 \% \mathrm{NP}-40,2 \mathrm{mmol} / 1$ vanadate, $1 \mathrm{mmol} / 1$ dithiothreitol (DTT) and $2.5 \mathrm{mmol} / 1$ phenylmethylsulfonyl fluoride]. The lysates were centrifuged at $12,000 \mathrm{x} g$ for $20 \mathrm{~min}$ at $4^{\circ} \mathrm{C}$, and aliquots of the supernatant were removed for protein concentration quantification using the Bradford assay (Coomassie Protein Reagent, Pierce; Thermo Fisher Scientific, Inc.). All Flag-tagged proteins were immunoprecipitated with $30 \mu \mathrm{l}$ of the $50 \%$ slurry of anti-FLAG M2 agarose (15 ul of packed beads; cat. no. A2220; Sigma-Aldrich; Merck KGaA) and the agarose beads were washed twice with RIPA buffer. Then, the agarose beads were mixed with SDS loading buffer and resolved on an $8 \%$ gel by SDS-PAGE and transferred to a polyvinylidene fluoride membrane (EMD Millipore). After blocking with $3 \%$ skimmed milk for $30 \mathrm{~min}$ at room temperature, the membranes were immunoblotted with PGC-1 $\alpha$
(1:500; cat. no. SC-13067; Santa Cruz Biotechnology, Inc.) and acetyl-lysine antibodies (1:1,000; cat. no. 9441; Cell Signaling Technology, Inc.) overnight at $4^{\circ} \mathrm{C}$ and then washed three times with TBS with Tween-20. The membranes were incubated with peroxidase-conjugated anti-rabbit IgG secondary antibody (1:3,000; cat. no. SC2357; Santa Cruz Biotechnology, Inc.) for $1 \mathrm{~h}$ at room temperature. All immunoreactive bands were visualized using an enhanced chemiluminescence detection system (Amersham ECL Prime Western Blotting Detection Reagent; cat. no. RPN2232; GE Healthcare) and the band intensities were determined using Quantity One-4.6.8. (basic) analysis software (Bio-Rad Laboratories, Inc.), which is a one-dimensional image analysis program.

Measurement of SIRT-1 activity. SIRT1 activity was measured using a fluorescence-based SIRT1 assay kit (Sigma-Aldrich; Merck KGaA) following the protocol provided. Cell nuclei were isolated in hypotonic buffer solution $(20 \mathrm{mM}$ Tris- $\mathrm{HCl}$, $\mathrm{pH} 7.4,10 \mathrm{mM} \mathrm{NaCl}$ and $3 \mathrm{mM} \mathrm{MgCl}_{2}$ ) with $0.5 \%$ of $\mathrm{NP} 40$, followed by centrifugation at $1,700 \mathrm{xg}$ for $10 \mathrm{~min}$ at $4^{\circ} \mathrm{C}$. The reaction was started by mixing $50 \mu \mathrm{l}$ nuclear extract and $50 \mu 1$ sirtuin assay buffer (fluorescence-conjugated human p53 peptides and $\mathrm{NAD}^{+}$). The reaction was incubated for $30 \mathrm{~min}$ at room temperature without light, after which $10 \mathrm{ml}$ developer was added. The absorbance was measured at an excitation wavelength of $380 \mathrm{~nm}$ and an emission wavelength of $460 \mathrm{~nm}$.

Measurement of histone deacetylase (HDAC) activity. HDAC activity in the cell nucleus was measured using an HDAC colorimetric assay kit (cat. no. N\#331-100; BioVision, Inc.) according to the manufacturer's protocol. Briefly, HSMMS treated with GLP-1 at various times. Nuclei were isolated in hypotonic buffer solution (20 mM Tris- $\mathrm{HCl}, \mathrm{pH} 7.4,10 \mathrm{mM} \mathrm{NaCl}$ and $3 \mathrm{mM} \mathrm{MgCl} 2$ ) with $0.5 \%$ of $\mathrm{NP} 40$, followed centrifugation at $1,700 \mathrm{x} g$ for $10 \mathrm{~min}$ at $4^{\circ} \mathrm{C}$. Nuclei protein extracted with HDAC $1 \mathrm{X}$ assay buffer which was supplied by assay kit. Then, $40 \mu \mathrm{g}$ nuclear protein from each group was added to a 96-well tissue culture plate at a final volume of $100 \mu \mathrm{l}$ per well. Reaction buffer and enzyme were added according to the manufacturer's recommendations. After incubation, HDAC activity was measured by scanning with an ELISA reader with a $450 \mathrm{~nm}$ filter.

Quantitative RT-PCR. Total RNA was extracted from the HSMMs using TRIzol ${ }^{\circledR}$ reagent (Invitrogen; Thermo Fisher Scientific, Inc.). cDNA was synthesized by RT-PCR using the Takara RNA PCR kit (AMV) ver 3. (cat. no. RR019) supplied by Takara Bio, Inc. The first strand cDNA was synthesized from $1 \mathrm{~g}$ total RNA using the AMV reverse transcriptase and the random 9-mer oligo-nucleotide. The $\mathrm{RT}$ reaction was performed for 1 cycle under the condition of $30^{\circ} \mathrm{C}$ for $10 \mathrm{~min}$, $42^{\circ} \mathrm{C}$ for $30 \mathrm{~min}, 95^{\circ} \mathrm{C}$ for $5 \mathrm{~min}$ and $5^{\circ} \mathrm{C}$ for $5 \mathrm{~min}$. PCR (Takara Bio, Inc.) was conducted using the SYBR Premix Ex Taq (Takara Bio, Inc.) and the following primers: GLUT4 forward, 5'-TTCTCTGCGGTGCTTGGCTC-3' and reverse 5'-TCCCCAGCCACGTCTCATTG-3'; GAPDH forward, 5'-GAGTCAACGGATTTGGACGT-3' and reverse 5'-GAC AAGCTTCCCGTTCTCAG-3'; and SIRT1 forward, 5'-TTG GACTCTGGCATGTCCCA-3' and reverse 5'-CATTTTCCA TGGCGCTGAGG-3'. The PCR cycle included a holding stage for $30 \mathrm{sec}$ at $95^{\circ} \mathrm{C}$ and cycling stage for $5 \mathrm{sec}$ at $95^{\circ} \mathrm{C}$ and 
$30 \mathrm{sec}$ at $60^{\circ} \mathrm{C}$. Changes in GLUT4 or SIRT1 gene expression were normalized to the housekeeping gene GAPDH and were quantified using the $2^{-\Delta \Delta C q}$ method (21).

Small interfering RNAs. The 21-nucleotide small interfering RNA (siRNA) duplexes for green fluorescent protein (GFP; 5'-GUUCAGCGUGUCCGGCGAGTT-3'), SIRT1 (5'-GGA UAGAGCCUCACAUGCAUU-3'), and GLUT4 (5'-GAU UGAACAGAGCUACAAU-3') were designed and created at Genolution Pharmaceuticals. The cells were transfected with the siRNA oligonucleotides and cDNA (pCDNA3 plasmid) using a pipette-type electroporator (Digital Biotechnology) according to the manufacturer's protocol (pulse voltage, $1,005 \mathrm{~V}$; pulse width, $35 \mathrm{msec}$; pulse number 2). Briefly, the cells were transfected with $100 \mathrm{pg}$ of each siRNA, cDNA, or $3 \mu \mathrm{g}$ pcDNA3 in $100 \mu \mathrm{l} \mathrm{R}$ bu-er. After transfection, the cells were seeded in six-well plates, allowed to differentiate for 3 days and treated with or without GLP-1.

Western blot analysis. The levels of GLUT4 (1:1,000; cat. no. 2213; overnight at $\left.4^{\circ} \mathrm{C}\right)$, GAPDH $(14 \mathrm{C} 10 ; 1: 2,000$; cat. no. $2118 ; 2 \mathrm{~h}$ at room temperature), Akt (1:2,000; cat. no. 9272 ; overnight at $4^{\circ} \mathrm{C}$ ), and PKA (PKA c- $\alpha ; 1: 2,000$; cat. no. 4782 ; overnight at $4^{\circ} \mathrm{C}$ ) were determined using antibodies from Cell Signaling Technology, Inc. SIRT1 (1:10,000; cat. no. SC-15404; overnight at $\left.4^{\circ} \mathrm{C}\right)$, and IRS-1 (1:2,000; cat. no. SC-559; overnight at $4^{\circ} \mathrm{C}$ ) antibodies were obtained from Santa Cruz Biotechnology, Inc. Cytoskeletal actin antibodies (1:10,000; cat. no. A300-491A; $1 \mathrm{~h}$ at room temperature) were obtained from Bethyl Laboratories, Inc. The levels of IRS-1, Akt, and PKA were determined using antibodies specific for phospho-IRS-1 (p-IRS-1; PY612; 1:500; cat. no. MBS624304; BioSource, Inc.), phospho-Akt (p-Akt; Ser473; 1:1,000; cat. no. 9275; Cell Signaling Technology, Inc.) and phospho-PKA C (p-PKA C; Thr197; 1:1,000; cat. no. 4781; Cell Signaling Technology, Inc.) overnight at $4^{\circ} \mathrm{C}$. The HSMMs were homogenized at $4^{\circ} \mathrm{C}$ in lysis buffer [20 mmol/l Tris (pH 8.0), $137 \mathrm{mmol} / \mathrm{l} \mathrm{NaCl}$, $1 \mathrm{mmol} / 1 \mathrm{MgCl}_{2}, 2 \mathrm{mmol} / 1 \mathrm{CaCl}_{2}, 1 \% \mathrm{NP}-40,2 \mathrm{mmol} / \mathrm{l}$ vanadate, $1 \mathrm{mmol} / \mathrm{l} \mathrm{DTT}, 2.5 \mathrm{mmol} / 1$ phenylmethylsulfonyl fluoride], $0.12 \mathrm{~g} / \mathrm{ml}$ nicotinamide, $1 \mathrm{~mol} / \mathrm{l}$ trichostatin $\mathrm{A}$, and the resulting lysate was centrifuged for $20 \mathrm{~min}$ at $12,000 \mathrm{xg}$ and $4^{\circ} \mathrm{C}$. Aliquots of the supernatant were removed for protein quantification using the Bradford assay (Coomassie Protein Reagent; Pierce; Thermo Fisher Scientific, Inc.). The supernatant was incubated in SDS sample buffer (100 mmol/l DTT and $100 \mu \mathrm{g}$ sample) for $5 \mathrm{~min}$ at $95^{\circ} \mathrm{C}$ and resolved by SDS-PAGE on a $10 \%$ gel, and the separated proteins were transferred to a polyvinylidene fluoride membrane (EMD Millipore). After blocking with 3\% skimmed milk for $30 \mathrm{~min}$ at room temperature, the membranes were incubated with primary antibodies as mentioned above and then a peroxidase-conjugated anti-rabbit IgG secondary antibody (1:3,000; cat. no. SC2357; Santa Cruz Biotechnology, Inc.) for $1 \mathrm{~h}$ at room temperature. All immunoreactive bands were visualized using an enhanced chemiluminescence detection system (Amersham ECL Prime Western Blotting Detection Reagent; cat. no. RPN2232; GE Healthcare), and the band intensities were determined using a Quantity One-4.6.8 (basic) analysis software (Bio-Rad Laboratories, Inc.), which is a one-dimensional image analysis program. The levels of each protein were normalized to the total protein values.
Statistical analysis. All results are presented as the mean \pm standard deviation consisting of at least three independent experiments, and all statistical analyses were performed using SPSS (version 19.0; IBM Corp.). A Student's t-test was used for comparison of two dependent groups and ANOVA with post-hoc tests (Bonferroni test) was used for comparison of multiple groups. $\mathrm{P}<0.05$ was considered to indicate a statistically significant difference.

\section{Results}

GLP-1 reverses palmitate-induced insulin resistance in HSMMs. When treated with palmitate (100 or 200 umol/l) in HSMMs, no significant viability reduction was noted (Fig. S1). The expression of the GLP-1 receptor in human skeletal muscle tissue was confirmed (Fig. S2) and then analysed further; there was an increase following exposure to recombinant GLP-1 (200 nmol/l). To demonstrate the effects of GLP-1 in HSMMs exposed to palmitate, the levels of 2-NBDG uptake, GLUT4 mRNA, and GLUT4 promoter activity were measured in palmitate-treated (200 $\mu \mathrm{mol} / \mathrm{l})$ or palmitate-(200 $\mu \mathrm{mol} / \mathrm{l})$ and GLP-1-treated (100 or $200 \mathrm{nmol} / \mathrm{l}$ ) cells. Compared with basal conditions, there was a significant increase in glucose uptake in HSMMs exposed to GLP-1 ( $\mathrm{P}<0.05$; Fig. 1A) and a significant decrease in glucose uptake in HSMMs exposed to palmitate $(\mathrm{P}<0.05$; Fig. 1A). The co-administration of palmitate and GLP-1 (200 nmol/l) significantly restored the palmitate-induced reduction in glucose uptake compared with treatment with palmitate $(200 \mu \mathrm{mol} / \mathrm{l})$ alone $(\mathrm{P}<0.05)$ regardless of whether insulin was present (Fig. 1A).

There was an elevation in GLUT4 mRNA in HSMMs treated with GLP-1 compared with basal conditions $(\mathrm{P}<0.05$; Fig. 1B). When palmitate and GLP-1 were co-administered, GLP-1 significantly restored the palmitate-induced reductions in GLUT4 mRNA, compared with palmitate $(200 \mu \mathrm{mol} / \mathrm{l})$ alone $(\mathrm{P}<0.05$; Fig. 1B). GLUT4 promoter activity was measured using a luciferase assay. Similar to the glucose uptake and GLUT4 mRNA results, GLP-1 increased GLUT4 promoter activity $(\mathrm{P}<0.05$ for both 100 and $200 \mathrm{nmol} / \mathrm{l} \mathrm{GLP-1}$; Fig. 1C) and palmitate decreased GLUT4 promoter activity $(\mathrm{P}<0.05$; Fig. $1 \mathrm{C})$ compared with basal conditions. When GLP-1 and palmitate were co-administered, GLP-1 (100 and $200 \mathrm{nmol} / \mathrm{l}$ ) significantly restored GLUT4 promoter activity levels, compared with palmitate $(200 \mu \mathrm{mol} / \mathrm{l})$ alone $(\mathrm{P}<0.05$ for both 100 and 200 nmol/1 GLP-1 with palmitate; Fig. 1C). There were also consistent results in GLUT4 protein expression in GLP-1-only, palmitate-only, and GLP-1 and palmitate treatment conditions (Fig. 1D). To determine whether the enhanced glucose uptake of GLP-1 by HSMMs was mediated by GLUT4, glucose uptake in cells treated with siRNA targeting GLUT4 was measured. The knockdown of GLUT4 significantly decreased glucose uptake $(\mathrm{P}<0.05$; Fig. 1E and F). These findings suggest GLP-1 restored palmitate-induced decreases in glucose uptake via restoration of GLUT4 expression and GLUT4 promoter stimulation in HSMMs. In other words, GLP-1 influences glucose uptake directly in human skeletal muscles under conditions of insulin resistance as well as via insulinotropic actions.

cAMP and PKA signaling cascades acts as downstream signals of GLP-1 in HSMMs. The classical downstream 
A

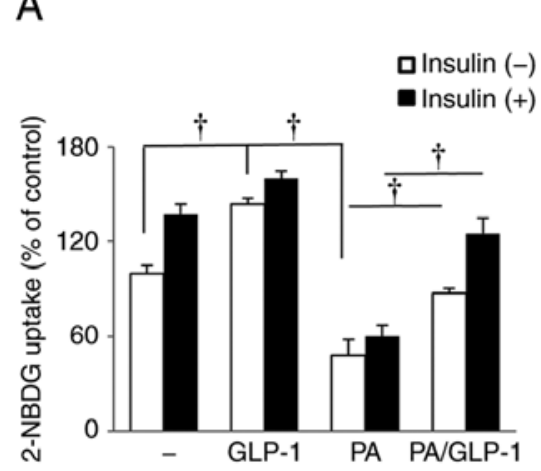

D
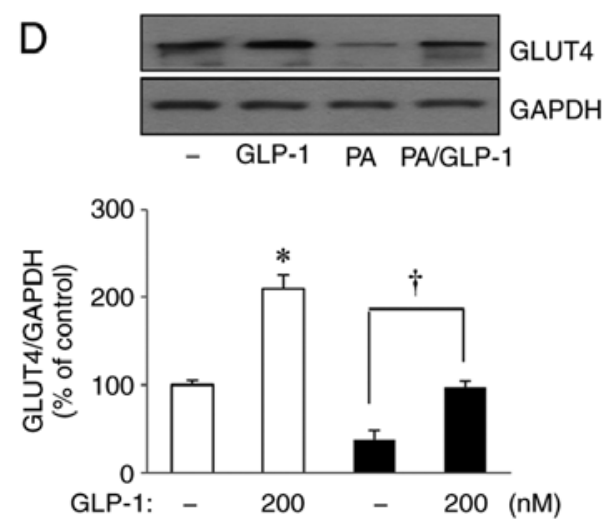

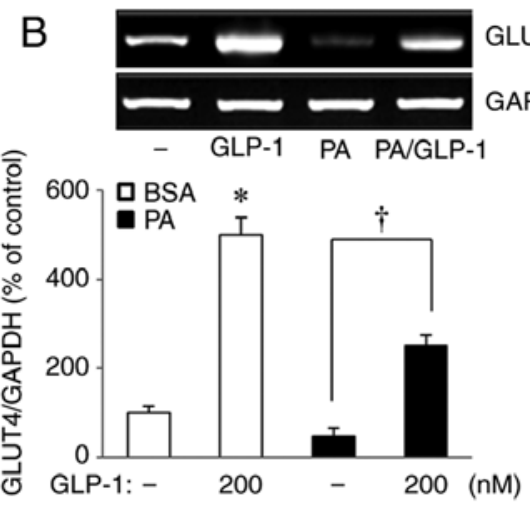

$\mathrm{E}$

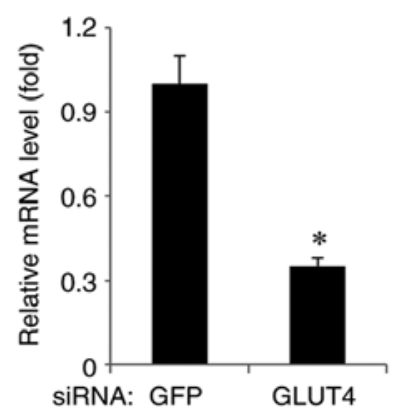

C

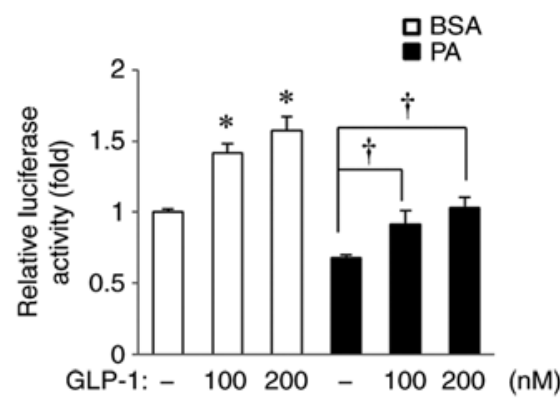

$\mathrm{F}$

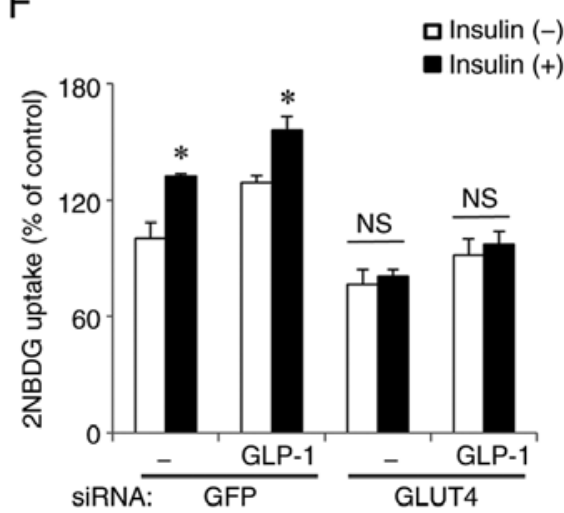

Figure 1. Effects of GLP-1 on glucose uptake and GLUT4 mRNA expression, promoter activity and protein expression in human skeletal muscle myotubes with or without exposure to PA. GLP-1 restores the PA-induced reduction in glucose uptake. GLP-1 reverses GLUT4 mRNA expression, promoter activity levels and GLUT4 protein expression. Knockdown of GLUT4 significantly decreases glucose uptake by GLP-1. Cells were exposed to $200 \mu$ mol/1 PA and 100 or $200 \mathrm{nmol} / \mathrm{l} \mathrm{GLP}-1$ for $24 \mathrm{~h}$. (A) Glucose uptake. (B) GLUT4 mRNA expression. (C) GLUT4 promoter activity. (D) GLUT4 protein expression. (E) Tansfection efficiency for siRNA GLUT4. (F) Glucose uptake by GLP-1 before and after siRNA transfection. " $\mathrm{P}<0.05$ vs. basal conditions; ${ }^{\dagger} \mathrm{P}<0.05$. 2-NBDG, 2-[N-(7-nitrobenz-2-oxa-1,3-diazol-4-yl)amino]-2-deoxy-D-glucose; PA, palmitate; GFP, green fluorescent protein; GLP-1, glucagon like peptide-1; GLUT4, glucose transporter type 4; siRNA, small interfering RNA; NS, not significant.

signals of GLP-1 in pancreatic $\beta$ cells, PKA, and cAMP, were investigated in relation to the activation of GLP-1 in HSMMs. The changes in cAMP were time-dependent; compared with the baseline, cAMP levels exhibited a significant elevation 15 min $(\mathrm{P}<0.05)$, peaking $30 \mathrm{~min}(\mathrm{P}<0.05)$, after treatment with $200 \mathrm{nmol} / 1$ GLP-1 (Fig. 2A). Following treatment with GLP-1, there was a consistent and significant increase in p-PKA C levels in relation to the GLP-1 concentration, compared with basal conditions $(\mathrm{P}<0.05$ and $\mathrm{P}<0.05$ for 100 and $200 \mathrm{nmol} / \mathrm{l}$ GLP-1, respectively; Fig. 2B). The suppression by PKA inhibitor (H89) of the GLP-1-induced increases in GLUT4 protein $(\mathrm{P}<0.05$ and $\mathrm{P}<0.05$ at 10 and $20 \mu \mathrm{mol} / 1 \mathrm{H} 89$, respectively; Fig. 2C) suggested that the PKA/cAMP signaling pathway is involved in the increase in GLUT4 expression induced by GLP-1.

GLP-1 leads to the deacetylation of PGCl $\alpha$ and increases SIRT1 activity in HSMMs. To determine the linkage between GLP-1 and SIRT1 in HSMMs, the deacetylation levels of PGC1 $\alpha$ were assessed after GLP-1 (200 nmol/l) was added to HSMMs overexpressing Flag-tagged PGC1 $\alpha$. SIRT1 has been shown to induce PGC1 $\alpha$ deacetylation (22). Immunoblot assays using the indicated antibodies were performed after HSMMs expressing Flag-tagged PGC-1 $\alpha$ were immunoprecipitated by antibodies targeting the Flag-tag. GLP-1 decreased the levels of acetylated PGC1 $\alpha$ (Fig. 3A), indicating the presence of GLP-1-activated deacetylases, such as SIRT1. Thus, in HSMMs treated with GLP-1, SIRT1 activity was proportional to the GLP-1 concentration (Fig. 3B). PKA is an enhancer of SIRT1 activity (23) and a downstream signal of GLP-1, as also demonstrated above. The PKA inhibitor, H89, suppressed SIRT1 activity which was stimulated by GLP-1 (200 nmol/l; Fig. 3C). In a further experiment, involvement of HDAC-mediated deacetylation, in addition to SIRT1 activity in GLP-1-treated cells was ruled out (Fig. 3D).

Inhibition of SIRT1 activity suppresses GLP-1-induced GLUT4 expression in HSMMs. To confirm the role of SIRT1 during GLP-1 activity in HSMMs, the SIRT1 inhibitor EX527 was applied to the cells, and GLUT4 mRNA levels were assessed using reverse transcription PCR. EX527 $(10 \mu \mathrm{mol} / \mathrm{l})$ significantly repressed GLP-1-induced GLUT4 mRNA expression in HSMMs exposed to GLP-1 alone (200 nmol/1; $\mathrm{P}<0.05$; Fig. 4A) and with co-administered palmitate $(200 \mu \mathrm{mol} / \mathrm{l})$ and GLP-1 (200 nmol/1; P<0.05; Fig. 4B). Simultaneously, SIRT1 activity was measured in cells treated with GLP-1 and/or palmitate and/or EX527. GLUT4 mRNA expression levels were correlated with the levels of SIRT1 activity (Fig. 4C). To confirm the SIRT1 dependence of GLP-1 activity in HSMMs, the cells were treated with SIRT1 siRNA. The transfection 


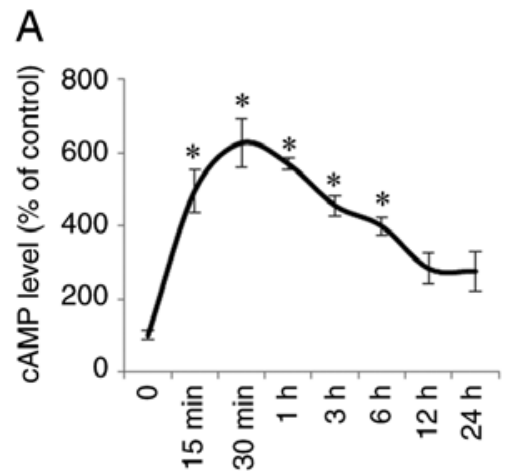

GLP-1
B
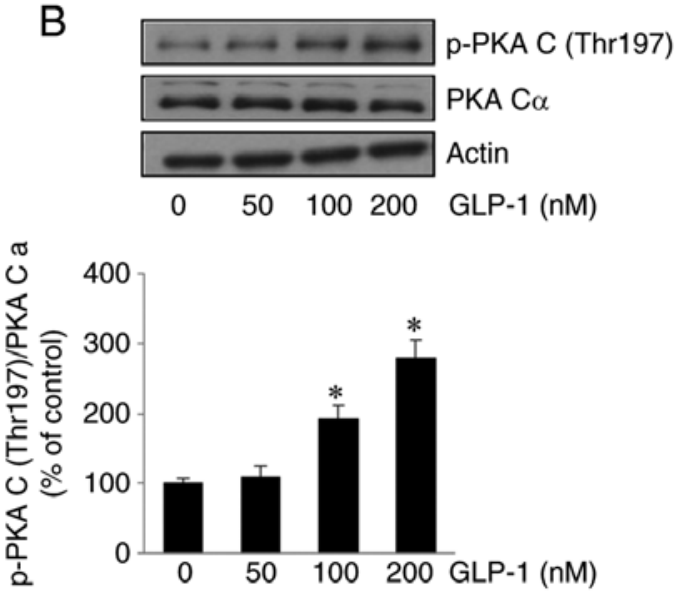

C
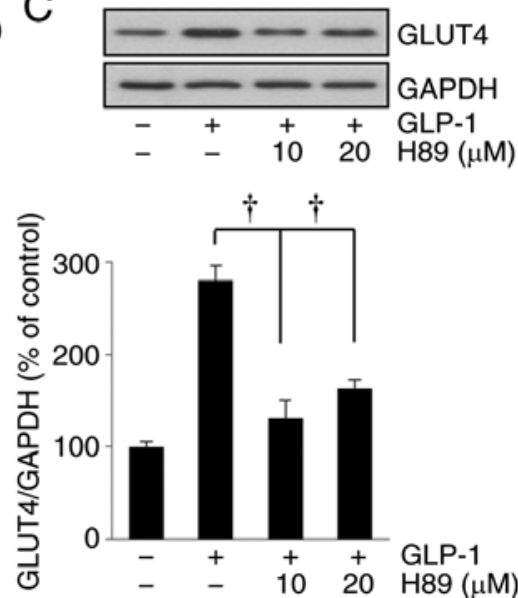

Figure 2. Changes in cAMP and PKA signals according to the GLP-1 concentration and exposure time, and the effect of the PKA inhibitor on GLP-1-induced GLUT4 expression. The cAMP and PKA signaling cascades act as downstream signals of GLP-1 in human skeletal muscle myotubes. (A) cAMP levels are significantly elevated for $24 \mathrm{~h}$ in GLP-1-treated cells. (B) Increase in p-PKA C levels as a function of the GLP-1 concentration. (C) PKA inhibitor blocks the enhancement of GLUT4 protein expression by GLP-1. " $\mathrm{P}<0.05$ vs. basal condition; ${ }^{\dagger} \mathrm{P}<0.05$. cAMP, cyclic adenosine monophosphate; PKA, protein kinase A; GLP-1, glucagon like peptide-1; GLUT4, glucose transporter type 4; p, phosphorylated.
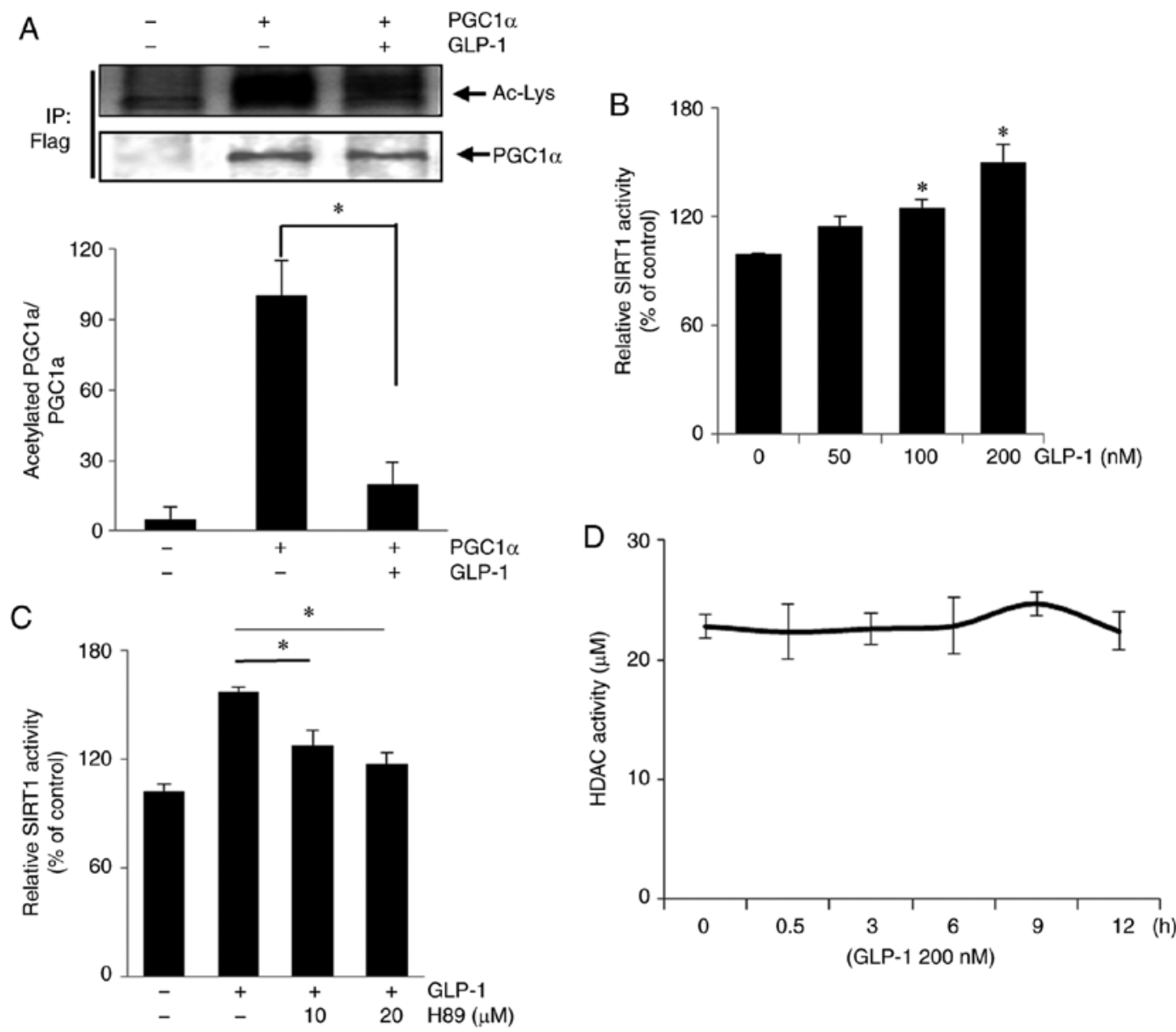

Figure 3. Effects of GLP-1 on SIRT1 activity in human skeletal muscle myotubes. GLP-1 elevates both (A) the deacetylation of PGC1 $\alpha$ and (B) SIRT1 activity. ${ }^{*} \mathrm{P}<0.05$. (C) PKA inhibitor (H89) reduces SIRT1 activity. "P<0.05 vs. basal condition. (D) GLP-1 has no effect on HDAC activity. IP, immunoprecipitation; Ac-Lys, acetylated lysine residues; HDAC, histone deacetylase; SIRT1, sirtuin 1; GLP-1, glucagon like peptide-1; GLUT4, glucose transporter type 4; PGC1 $\alpha$, peroxisome proliferator-activated receptor $\gamma 1 \alpha$.

efficiency on the expression of SIRT1 was demonstrated with the si-SIRT1 plasmid (Fig. S3). Consistent with the results obtained using the SIRT1 inhibitor, SIRT1 siRNA significantly suppressed the GLP1-induced enhancement of GLUT4 expression in HSMMs with/without palmitate $(\mathrm{P}<0.05$; Fig. 4D; palmitate, $200 \mu \mathrm{mol} / 1, \mathrm{P}<0.05$; Fig. 4E). These findings 

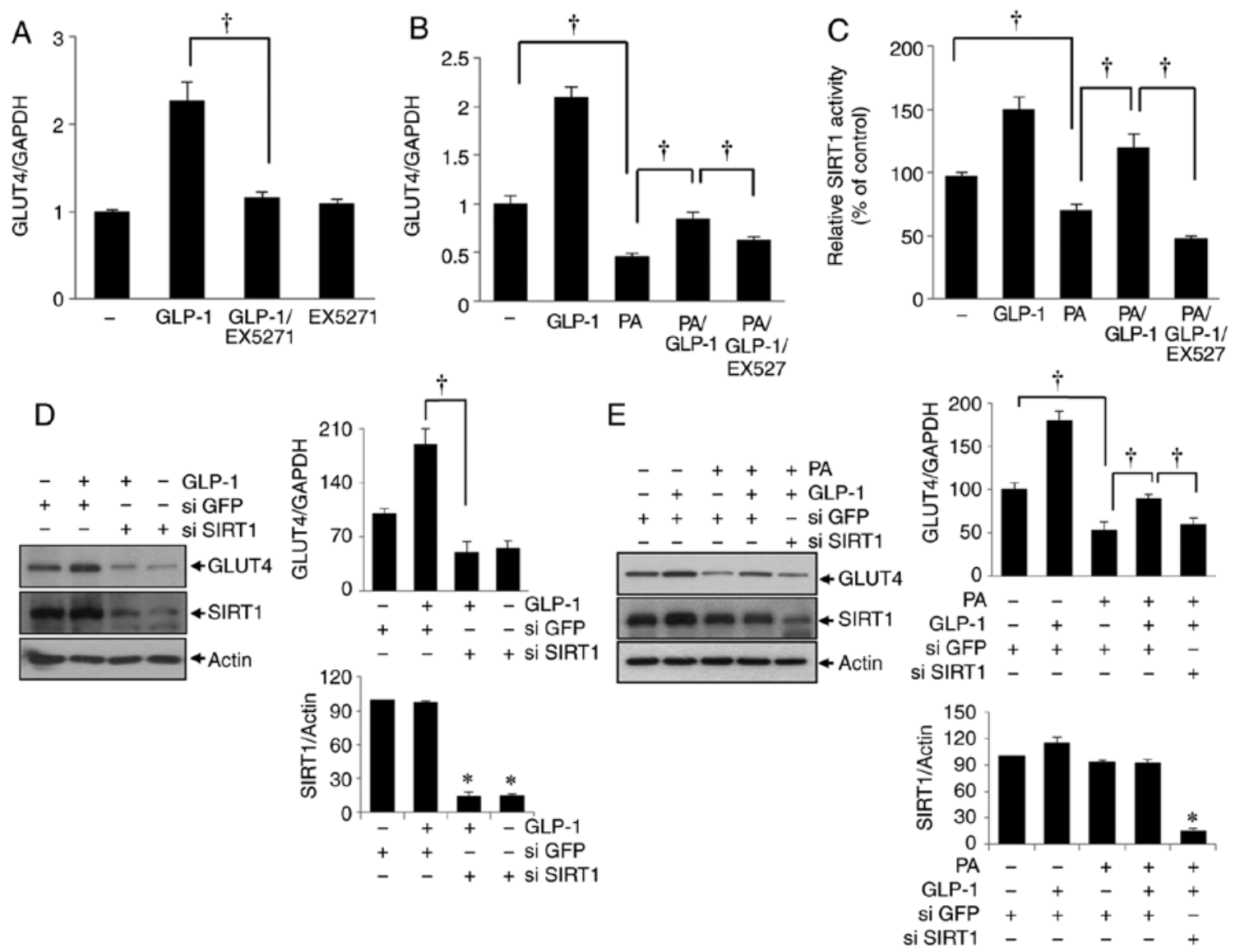

Figure 4. Effects of SIRT1 inhibition of GLUT4 expression in HSMMs exposed to GLP-1 and/or PA. SIRT1 inhibitor (EX527) and SIRT1 siRNA limit the effects of GLP-1 on GLUT4 expression in HSMMs exposed to PA. GLUT4 mRNA expression (A) without PA and (B) with PA. (C) SIRT1 activity. (D) GLUT4 protein expression before and after siRNA SIRT1 treatment and (E) with PA. 'P<0.05. PA, palmitate; HSMMs, human skeletal muscle myotubes; SIRT1, sirtuin 1; GLP-1, glucagon like peptide-1; GLUT4, glucose transporter type 4; si, small interfering.; GFP, green fluorescent protein.

suggest the restoration of GLP-1-induced GLUT4 expression was mediated by SIRT1 in HSMMs exposed to palmitate.

The SIRT1 inhibitor EX527 suppresses the GLP-1-induced phosphorylation of IRS-1 and Akt in HSMMs exposed to palmitate. The present study investigated whether GLP-1 influenced the activation of insulin signaling pathways and whether SIRT1 was involved in the reversal of insulin resistance by GLP-1 in HSMMs exposed to palmitate. The differentiated HSMMs were treated with palmitate, recombinant GLP-1, and/or EX527 for $24 \mathrm{~h}$ and then stimulated with insulin for $30 \mathrm{~min}$. The phosphorylation levels of IRS-1 and Akt (proteins related to insulin signaling pathways) in HSMMs exposed to palmitate $(200 \mu \mathrm{mol} / \mathrm{l})$ and GLP-1 $(200 \mathrm{nmol} / \mathrm{l})$ were simultaneously determined by adding EX527 $(10 \mu \mathrm{mol} / \mathrm{l})$ to the cells. GLP-1 increased, while palmitate decreased the phosphorylation of IRS-1 in HSMMs exposed to insulin. Palmitate decreased the phosphorylation of proteins in the insulin signalling cascade, such as IRS-1 and Akt (Fig. 5). When GLP-1 and palmitate were co-administered, GLP-1 significantly reversed the palmitate-induced reduction in insulin signaling in HSMMs exposed to insulin compared with palmitate $(200 \mu \mathrm{mol} / \mathrm{l})$ and insulin (100 nmol/l; P<0.05; Fig. 5). Moreover, in HSMMs exposed to both palmitate and GLP-1 in conjunction with insulin, EX527 limited the GLP-1-induced enhancement of phosphorylated IRS-1 and Akt compared with palmitate
(200 $\mu \mathrm{mol} / \mathrm{l})$, GLP-1 (200 nmol/l), and insulin (100 nmol/1; $\mathrm{P}<0.05$; Fig. 5). These findings suggest that GLP-1 functioned through SIRT1 and improved the palmitate-induced repression of insulin signaling pathways in HSMMs. A model of the present study is presented in Fig. 6 .

\section{Discussion}

The present study demonstrated that GLP-1 restores palmitate-induced reductions in glucose uptake and GLUT4 expression, and improves the palmitate-induced repression of insulin signaling pathways in HSMMs. These actions of GLP-1 were shown to be mediated by SIRT1. The glucose-lowering effect of GLP-1 involves several mechanisms, the most important of which is enhancement of glucose-dependent insulin secretion from pancreatic $\beta$ cells. GLP-1 also has extra-pancreatic actions, including in adipose tissue and skeletal muscle, both of which are major peripheral target organs for glucose control $(24,25)$. Independent of the incretin effect, GLP-1 plays a role in the stimulation of glucose disposal in insulin-sensitive tissues (26-28) and increases glucose uptake and GLUT1/GLUT4 expression in adipose tissue (24). In human skeletal muscle, GLP-1 stimulates glycogen synthesis and glucose uptake $(25,29)$. In the present study, the increased glucose uptake of GLP-1 in HSMMs was shown to be mediated by GLUT4. GLP-1 seems to influence glucose uptake by 

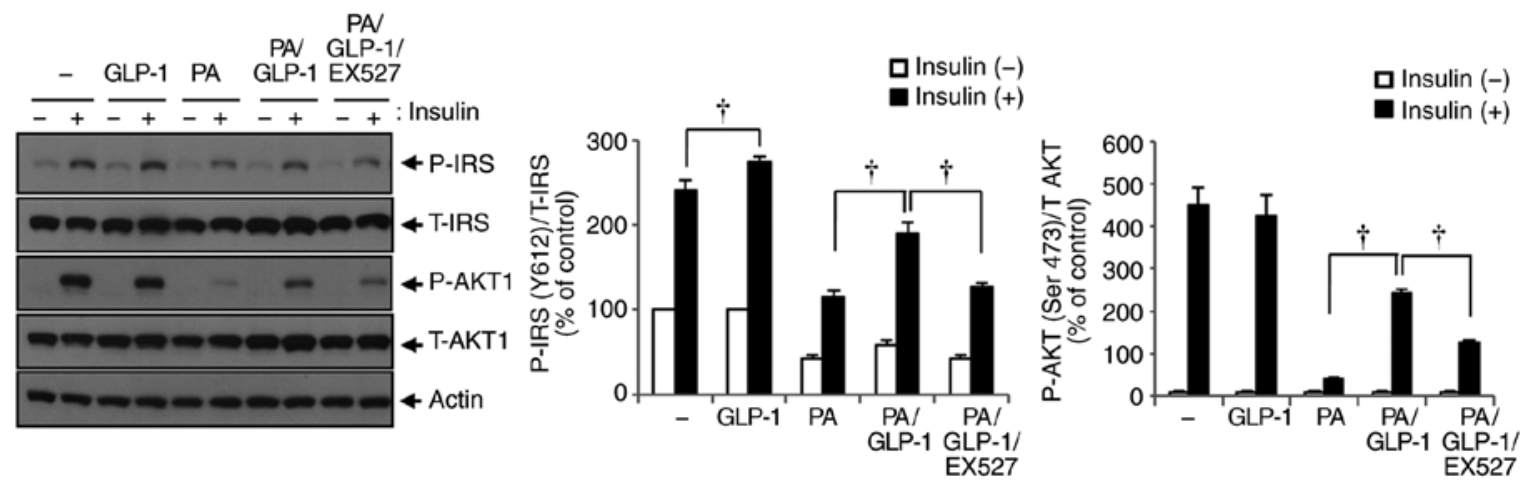

Figure 5. Effects of a SIRT1 inhibitor (EX527) on the phosphorylation of proteins (IRS-1 and Akt) related to insulin signaling in human skeletal muscle myotubes exposed to PA and GLP-1. EX527 represses the GLP-1-induced enhancement of P-IRS-1 and Akt. Treatment with $100 \mathrm{nmol} / 1 \mathrm{insulin}$ for $15 \mathrm{~min}$. ${ }^{\dagger} \mathrm{P}<0.05$. IRS-1, insulin receptor substrate 1; Akt, protein kinase B; PA, palmitate; SIRT1, sirtuin 1; GLP-1, glucagon like peptide-1; P, phosphorylated; T, total.

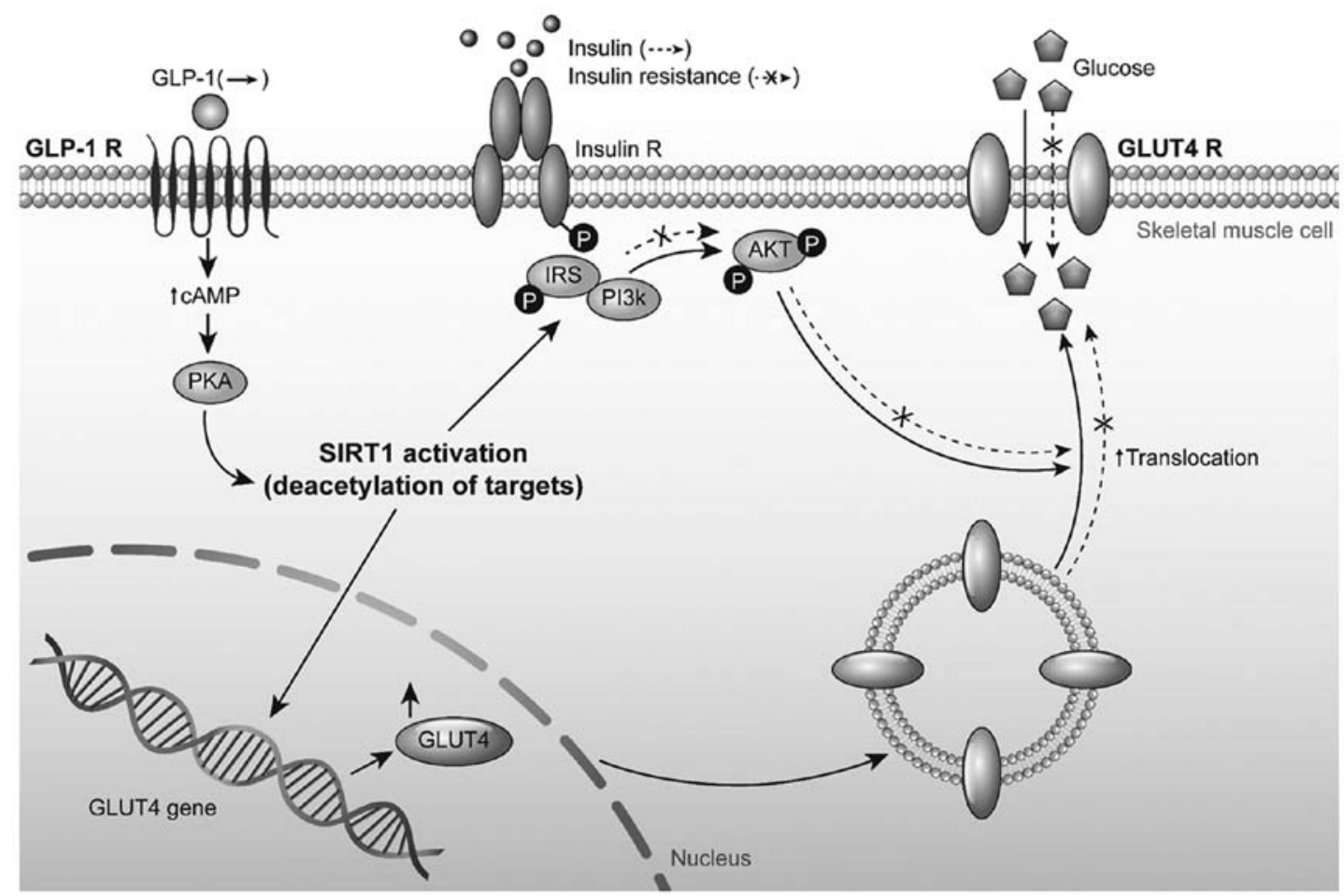

Figure 6. A working model of the GLP-1, SIRT1 and GLUT4 signalling pathway. GLP-1, glucagon like peptide-1; GLP-1 R, glucagon like peptide-1 receptor; insulin R, insulin receptor, GLUT4 R, GLUT4 receptor; SIRT1, sirtuin 1; PKA, protein kinase A; PI3K, phosphoinositide 3 kinase; IRS, insulin receptor substrate; $\mathrm{P}$, phosphate; cAMP, cyclic adenosine monophosphate.

increasing both GLUT4 levels at the plasma membrane and total GLUT4 levels, although this has yet to be confirmed in other studies (29-31). For example, a previous study reported that GLP-1 has no direct effect on glucose uptake in human skeletal muscle (32). However, short-term treatment (1-2 h) with GLP-1 in individuals with normal blood glucose may have little effect on GLUT4 translocation and total GLUT4 expression; this may explain the differences between studies regarding the effects of GLP-1 on the glucose concentration (31).

SIRT1 is a promising treatment target for T2DM due to its roles in the regulation of glucose and lipid metabolism, insulin sensitization, and stimulation of insulin secretion (2,33-35). In pancreatic $\beta$ cells, GLP-1 inhibits SIRT1 activity which stimulates the mass expansion of $\beta$ cells, while SIRT1 acts as a negative regulator of $\beta$ cell proliferation and prevents the action of GLP-1 (19). In the mouse liver, a GLP-1 analogue activated SIRT1 and improved fat accumulation (16,17). However, the relationship between GLP-1 and SIRT1 in skeletal muscle cells, is unclear. Thus, in the present study whether SIRT1 influenced the action of GLP-1 during glucose uptake was examined. The results of the present study showed that GLP-1 activated SIRT1 and restored GLUT4 expression in HSMMs treated with palmitate.

The present study was also able to demonstrate that GLP-1 ameliorates insulin resistance via the activation of insulin signaling pathways in insulin-resistant HSMMs. The inhibition of IRS and Akt phosphorylation by a GLP-1 agonist enhanced GLUT4 translocation in palmitate-treated muscle cells (36). Moreover, in the present study, SIRT1 was shown to be involved in the GLP-1-induced activation of insulin signaling 
pathways, leading to enhancement of IRS and Akt phosphorylation. In contrast to pancreatic $\beta$ cells, the cell signaling cascades associated with GLP-1 in skeletal muscles have yet to be fully characterized. GLP-1 has been shown to activate the PI3K/Akt, p70s6k, p42, and p44 mitogen-activated protein kinase pathways in rat and human skeletal muscles $(9,37)$, but GLP-1 also influences glucose uptake via PI3K-dependent and Akt-independent mechanisms $(9,30,38)$. GLP-1 improves insulin sensitivity via insulin-mediated mechanisms including enhanced glucose disposal and suppression of endogenous glucose production in patients with type 2 diabetes, obesity, and normal glucose tolerance (38-40). Additionally, apart from its incretin effects, GLP-1 potentiates insulin action in depancreatised dogs (41). The effects of SIRT1 on insulin sensitivity remain unclear. SIRT1 may be the mediator that links caloric restriction to enhanced levels of insulin sensitivity within skeletal muscles (41).

Although GLP-1 receptors are present in skeletal muscles, they appear to be functionally different from those located in pancreatic $\beta$ cells, because muscle-specific GLP-1 receptors do not increase cAMP levels $(23,42)$. The present study reconfirmed that GLP-1 receptors are expressed in human skeletal muscles, which is consistent with the first report of GLP-1 receptor expression in human skeletal muscles (29). In contrast to previous studies of rat myotubes $(43,44)$, the present study showed that GLP-1 increased glucose uptake and GLUT4 expression through the cAMP/PKA pathway in HSMMs. cAMP levels rose 15 min after GLP-1 treatment and peaked at a six-fold increase over basal levels. A PKA inhibitor also suppressed the GLP-1 effect on GLUT4 expression. Moreover, downstream involvement of SIRT1 in the signaling pathway of GLP-1 was also determined. The activity of SIRT1 is controlled by various mechanisms, including expression changes through transcription factors, post-translational modifications, the formation of complexes with other proteins, and altered NAD ${ }^{+}$levels (43). SIRT1 activity is modulated by phosphorylation via the cAMP/PKA pathway $(14,15)$. In another study, SIRT1-mediated resveratrol was shown to be associated with an improvement of GLUT4 expression in muscles from T2DM mice (44). In conjunction with previous results, the findings of the present study suggest that SIRT1 mediates the GLP-1 induced enhancement of glucose uptake and GLUT4 expression through the cAMP/PKA pathway. Therefore, the cAMP/PKA pathway acts upstream of SIRT1, which is also consistent with previous reports $(14,15)$. The results of the present study suggest that, in insulin-resistant HSMMs, GLP-1 influences glucose metabolism through the GLP-1 receptor, cAMP/PKA pathway, SIRT1 activation and increased GLUT4 expression.

The expression of GLP-1 receptor in response to GLP-1 ligand seems to be different in each target tissue. $\beta$-cell expression of GLP-1 receptor was downregulated by GLP-1 (45). However, in endothelial cells, a GLP-1 agonist elevated GLP1 receptor level (46). This result from endothelial cells is consistent with data of the present study from skeletal muscle. Regulators of GLP-1 receptor expression are not fully understood although miR-204 and transcription factor 7-like 2 (TCF7L2) in $\beta$-cells and TCF7L2 in endothelial cells were reported to be factors regulating GLP-1 receptor expression $(47,48)$. Further study is required to reveal the mechanism regarding GLP-1 receptor expression by GLP-1 in skeletal muscle.

The effects of SIRT1 on glucose homeostasis differ among liver, pancreas, and fat tissue $(12,34,48-51)$. There are several possible underlying mechanisms that may support SIRT-induced improvements in insulin sensitivity in skeletal muscles. For example, SIRT1 represses the expression of protein tyrosine phosphatase $1 \mathrm{~B}$ and increases the efficiency of PI3K signalling in response to caloric restriction $(52,53)$. In skeletal muscle, SIRT1 deacetylates PGC1 $\alpha$, induces mitochondrial fatty acid oxidation, and improves insulin sensitivity $(14,42,52)$. The findings of the present study provided an additional mechanism by which SIRT1 may beneficially influence glucose metabolism and insulin sensitivity as a mediator of GLP-1 function in HSMMs.

In conclusion, the present study investigated whether GLP-1 restores glucose uptake, as mediated by the cAMP/PKA signaling pathway and GLUT4, in addition to enhancing the activity of the insulin signaling pathway in palmitate-exposed HSMMs. The results of the present study provide evidence of the involvement of SIRT1 in the GLP-1-induced enhancement of glucose disposal and insulin signaling in insulin-resistant HSMMs.

\section{Acknowledgements}

Not applicable.

\section{Funding}

The present study was supported by the faculty research fund (JJ) of Ajou University School of Medicine and a grant (grant. no. NRF-2016-R1D1A1B03930214 to KL) of the National Research Foundation of Korea.

\section{Availability of data and materials}

The datasets used and/or analyzed during the current study are available from the corresponding author on reasonable request.

\section{Authors' contributions}

JJ, TK, SH, HK, DK, YK and KL contributed to the study design. JJ, SC, HL and EH performed the experiments for data acquisition. JJ, SC and EH performed the statistical analyses. TK, SH, HK, DK, HL and YK interpreted the experimental results. JJ and SC contributed to the drafting of the manuscript. All authors read and approved the final manuscript.

\section{Ethics approval and consent to participate}

Not applicable.

\section{Patient consent for publication}

Not applicable.

\section{Competing interests}

The authors declare that they have no competing interests. 


\section{References}

1. DeFronzo RA and Del Prato S: Insulin resistance and diabetes mellitus. J Diabetes Complications 10: 243-245, 1996.

2. Boden G: Free fatty acids (FFA), a link between obesity and insulin resistance. Front Biosci 3: d169-d175, 1998.

3. Minamino T, Komuro I and Kitakaze M: Endoplasmic reticulum stress as a therapeutic target in cardiovascular disease. Circ Res 107: 1071-1082, 2010.

4. Yuzefovych L, Wilson G and Rachek L: Different effects of oleate vs. palmitate on mitochondrial function, apoptosis, and insulin signaling in L6 skeletal muscle cells: Role of oxidative stress. Am J Physiol Endocrinol Metab 299: E1096-E1105, 2010.

5. Dasu MR and Jialal I: Free fatty acids in the presence of high glucose amplify monocyte inflammation via Toll-like receptors. Am J Physiol Endocrinol Metab 300: E145-E154, 2011.

6. Jung JG, Choi SE, Hwang YJ, Lee SA, Kim EK, Lee MS, Han SJ, Kim HJ, Kim DJ, Kang Y and Lee KW: Supplementation of pyruvate prevents palmitate-induced impairment of glucose uptake in C2 myotubes. Mol Cell Endocrinol 345: 79-87, 2011.

7. Lee MS, Choi SE, Ha ES, An SY, Kim TH, Han SJ, Kim HJ, Kim DJ, Kang Y and Lee KW: Fibroblast growth factor-21 protects human skeletal muscle myotubes from palmitate-induced insulin resistance by inhibiting stress kinase and NF-kB. Metabolism 61 : 1142-1151, 2012.

8. Nauck MA and Meier JJ: Incretin hormones: Their role in health and disease. Diabetes Obes Metab 20 (Suppl 1): S5-S21, 2018.

9. Acitores A, Gonzalez N, Sancho V, Valverde I and VillanuevaPenacarrillo ML: Cell signalling of glucagon-like peptide-1 action in rat skeletal muscle. J Endocrinol 180: 389-398, 2004.

10. D'Alessio DA, Prigeon RL and Ensinck JW: Enteral enhancement of glucose disposition by both insulin-dependent and insulin-independent processes. A physiological role of glucagon-like peptide I. Diabetes 44: 1433-1437, 1995.

11. Giannocco G, Oliveira KC, Crajoinas RO, Venturini G, Salles TA Fonseca-Alaniz MH, Maciel RM and Girardi AC: Dipeptidyl peptidase IV inhibition upregulates GLUT4 translocation and expression in heart and skeletal muscle of spontaneously hypertensive rats. Eur J Pharmacol 698: 74-86, 2013.

12. Banks AS, Kon N, Knight C, Matsumoto M, Gutiérrez-Juárez R, Rossetti L, Gu W and Accili D: SirT1 gain of function increases energy efficiency and prevents diabetes in mice. Cell Metab 8: 333-341, 2008

13. Feige JN, Lagouge M, Canto C, Strehle A, Houten SM, Milne JC, Lambert PD, Mataki C, Elliott PJ and Auwerx J: Specific SIRT1 activation mimics low energy levels and protects against diet-induced metabolic disorders by enhancing fat oxidation. Cell Metab 8: 347-358, 2008

14. Gerhart-Hines Z, Dominy JE Jr, Blattler SM, Jedrychowski MP, Banks AS, Lim JH, Chim H, Gygi SP and Puigserver P: The cAMP/PKA pathway rapidly activates SIRT1 to promote fatty acid oxidation independently of changes in $\mathrm{NAD}(+)$. Mol Cell 44: 851-863, 2011.

15. Lim JH, Gerhart-Hines Z, Dominy JE, Lee Y, Kim S, Tabata M, Xiang YK and Puigserver P: Oleic acid stimulates complete oxidation of fatty acids through protein kinase A-dependent activation of SIRT1-PGC1 $\alpha$ complex. J Biol Chem 288: 7117-7126, 2013

16. Xu F, Li Z, Zheng X, Liu H, Liang H, Xu H, Chen Z, Zeng K and Weng J: SIRT1 mediates the effect of GLP-1 receptor agonist exenatide on ameliorating hepatic steatosis. Diabetes 63 3637-3646, 2014

17. Lee J, Hong SW, Chae SW, Kim DH, Choi JH, Bae JC, Park SE, Rhee EJ, Park CY, Oh KW, et al: Exendin-4 improves steatohepatitis by increasing Sirtl expression in high-fat diet-induced obese C57BL/6J mice. PLoS One 7: e31394, 2012

18. Lee J, Hong SW, Park SE, Rhee EJ, Park CY, Oh KW, Park SW and Lee WY: Exendin-4 attenuates endoplasmic reticulum stress through a SIRT1-dependent mechanism. Cell Stress Chaperones 19: 649-656, 2014.

19. Bastien-Dionne PO, Valenti L, Kon N, Gu W and Buteau J: Glucagon-like peptide 1 inhibits the sirtuin deacetylase SirT1 to stimulate pancreatic $\beta$-cell mass expansion. Diabetes 60 : 3217-3222, 2011.

20. Kharitonenkov A, Wroblewski VJ, Koester A, Chen YF, Clutinger CK, Tigno XT, Hansen BC, Shanafelt AB and Etgen GJ: The metabolic state of diabetic monkeys is regulated by fibroblast growth factor-21. Endocrinology 148: 774-781, 2007.
21. Livak KJ and Schmittgen TD: Analysis of relative gene expression data using real-time quantitative PCR and the 2(-Delta Delta $\mathrm{C}(\mathrm{T})$ ) method. Methods 25: 402-408, 2001

22. Nemoto S, Fergusson MM and Finkel T: SIRT1 functionally interacts with the metabolic regulator and transcriptional coactivator PGC-1\{alpha\}. J Biol Chem 280: 16456-16460, 2005.

23. Houtkooper RH, Canto C, Wanders RJ and Auwerx J: The secret life of NAD+: An old metabolite controlling new metabolic signaling pathways. Endocr Rev 31: 194-223, 2010.

24. Holz GG: Epac: A new cAMP-binding protein in support of glucagon-like peptide-1 receptor-mediated signal transduction in the pancreatic beta-cell. Diabetes 53: 5-13, 2004.

25. Luque MA, Gonzalez N, Marquez L, Acitores A, Redondo A, Morales M, Valverde I and Villanueva-Peñacarrillo ML: Glucagon-like peptide-1 (GLP-1) and glucose metabolism in human myocytes. J Endocrinol 173: 465-473, 2002.

26. D'Alessio DA, Kahn SE, Leusner CR and Ensinck JW: Glucagon-like peptide 1 enhances glucose tolerance both by stimulation of insulin release and by increasing insulin-independent glucose disposal. J Clin Invest 93: 2263-2266, 1994.

27. Egan JM, Montrose-Rafizadeh C, Wang Y, Bernier M and Roth J: Glucagon-like peptide-1(7-36) amide (GLP-1) enhances insulin-stimulated glucose metabolism in 3T3-L1 adipocytes: One of several potential extrapancreatic sites of GLP-1 action. Endocrinology 135: 2070-2075, 1994.

28. Miki H, Namba M, Nishimura T, Mineo I, Matsumura T, Miyagawa J, Nakajima H, Kuwajima M, Hanafusa $T$ and Matsuzawa Y: Glucagon-like peptide-1(7-36)amide enhances insulin-stimulated glucose uptake and decreases intracellular cAMP content in isolated rat adipocytes. Biochim Biophys Acta 1312: 132-136, 1996

29. Green CJ,Henriksen TI, Pedersen BK and Solomon TP: Glucagon like peptide-1-induced glucose metabolism in differentiated human muscle satellite cells is attenuated by hyperglycemia. PLoS One 7: e44284, 2012.

30. Arnes L, Gonzalez N, Tornero-Esteban P, Sancho V, Acitores A, Valverde I, Delgado E and Villanueva-Peñacarrillo ML: Characteristics of GLP-1 and exendins action upon glucose transport and metabolism in type 2 diabetic rat skeletal muscle. Int J Mol Med 22: 127-132, 2008

31. Li Z, Ni CL, Yao Z, Chen LM and Niu WY: Liraglutide enhances glucose transporter 4 translocation via regulation of AMP-activated protein kinase signaling pathways in mouse skeletal muscle cells. Metabolism 63: 1022-1030, 2014.

32. Sjøberg KA, Holst JJ, Rattigan S, Richter EA and Kiens B: GLP-1 increases microvascular recruitment but not glucose uptake in human and rat skeletal muscle. Am J Physiol Endocrinol Metab 306: E355-E362, 2014

33. Rodgers JT, Lerin C, Haas W, Gygi SP, Spiegelman BM and Puigserver P: Nutrient control of glucose homeostasis through a complex of PGC-1alpha and SIRT1. Nature 434: 113-118, 2005.

34. Yu J and Auwerx J: The role of sirtuins in the control of metabolic homeostasis. Ann N Y Acad Sci 1173 (Suppl 1): E10-E19, 2009

35. Quiñones M, Al-Massadi O, Fern $\varnothing \mathrm{J}$ and Nogueiras R: Cross-talk between SIRT1 and endocrine factors: Effects on energy homeostasis. Mol Cell Endocrinol 397: 42-50, 2014

36. Li Z, Zhu Y, Li C, Tang Y, Jiang Z, Yang M, Ni CL, Li D, Chen L and Niu W: Liraglutide ameliorates palmitate-induced insulin resistance through inhibiting the IRS-1 serine phosphorylation in mouse skeletal muscle cells. J Endocrinol Invest 41: 1097-1102, 2018.

37. Gonzalez N, Acitores A, Sancho V, Valverde I and VillanuevaPenacarrillo ML: Effect of GLP-1 on glucose transport and its cell signalling in human myocytes. Regul Pept 126: 203-211, 2005.

38. Egan JM, Meneilly GS, Habener JF and Elahi D: Glucagon-like peptide-1 augments insulin-mediated glucose uptake in the obese state. J Clin Endocrinol Metab 87: 3768-3773, 2002.

39. Zander M, Madsbad S, Madsen JL and Holst JJ: Effect of 6-week course of glucagon-like peptide 1 on glycaemic control, insulin sensitivity, and beta-cell function in type 2 diabetes: A parallel-group study. Lancet 359: 824-830, 2002.

40. Seghieri M, Rebelos E, Gastaldelli A, Astiarraga BD, Casolaro A, Barsotti E, Pocai A, Nauck M, Muscelli E and Ferrannini E: Direct effect of GLP-1 infusion on endogenous glucose production in humans. Diabetologia 56: 156-161, 2013.

41. Sandhu H, Wiesenthal SR, MacDonald PE, McCall RH, Tchipashvili V, Rashid S, Satkunarajah M, Irwin DM, Shi ZQ, Brubaker PL, et al: Glucagon-like peptide 1 increases insulin sensitivity in depancreatized dogs. Diabetes 48: 1045-1053, 1999. 
42. Yang H, Egan JM, Wang Y, Moyes CD, Roth J, Montrose MH and Montrose-Rafizadeh C: GLP-1 action in L6 myotubes is via a receptor different from the pancreatic GLP-1 receptor. Am J Physiol 275: C675-C683, 1998.

43. Houtkooper RH, Pirinen E and Auwerx J: Sirtuins as regulators of metabolism and healthspan. Nat Rev Mol Cell Biol 13 : 225-238, 2012

44. Yonamine CY, Pinheiro-Machado E, Michalani ML, AlvesWagner AB, Esteves JV, Freitas HS and Machado UF: Resveratro improves glycemic control in Type 2 diabetic obese mice by regulating glucose transporter expression in skeletal muscle and liver. Molecules 22 pii: E1180: 2017.

45. Fehmann HC, Jiang J, Pitt D, Schweinfurth J and Goke B: Ligand-induced regulation of glucagon-like peptide-I receptor function and expression in insulin-secreting beta cells Pancreas 13: 273-282, 1996.

46. Liu L, Liu J, Wong WT, Tian XY, Lau CW, Wang YX, Xu G $\mathrm{Pu}$ Y, Zhu Z, Xu A, et al: Dipeptidyl peptidase 4 inhibitor sitagliptin protects endothelial function in hypertension through a glucagon-like peptide 1-dependent mechanism. Hypertension 60 : 833-841, 2012.

47. Jo S, Chen J, Xu G, Grayson TB, Thielen LA and Shalev A miR-204 controls glucagon-like peptide 1 receptor expression and agonist function. Diabetes 67: 256-264, 2018.

48. Kimura T, Obata A, Shimoda M, Okauchi S, Hirukawa H, Kohara K, Kinoshita T, Nogami Y, Nakanishi S, Mune T, et al: Decreased glucagon-like peptide 1 receptor expression in endothelial and smooth muscle cells in diabetic $\mathrm{db} / \mathrm{db}$ mice: TCF7L2 is a possible regulator of the vascular glucagon-like peptide 1 receptor. Diab Vasc Dis Res 14: 540-548, 2017.
49. Frescas D, Valenti L and Accili D: Nuclear trapping of the forkhead transcription factor FoxO1 via Sirt-dependent deacetylation promotes expression of glucogenetic genes. J Biol Chem 280: 20589-20595, 2005.

50. Bordone L, Motta MC, Picard F, Robinson A, Jhala US, Apfeld J, McDonagh T, Lemieux M, McBurney M, Szilvasi A, et al: Sirtl regulates insulin secretion by repressing UCP 2 in pancreatic beta cells. PLoS Biol 4: e31, 2006.

51. Lee JH, Song MY, Song EK, Kim EK, Moon WS, Han MK, Park JW, Kwon KB and Park BH: Overexpression of SIRT1 protects pancreatic beta-cells against cytokine toxicity by suppressing the nuclear factor-kappaB signaling pathway. Diabetes 58: 344-351, 2009.

52. Sun C, Zhang F, Ge X, Yan T, Chen X, Shi X and Zhai Q: SIRT1 improves insulin sensitivity under insulin-resistant conditions by repressing PTP1B. Cell Metab 6: 307-319, 2007.

53. Schenk S, McCurdy CE, Philp A, Chen MZ, Holliday MJ, Bandyopadhyay GK, Osborn O, Baar K and Olefsky JM: Sirt1 enhances skeletal muscle insulin sensitivity in mice during caloric restriction. J Clin Invest 121: 4281-4288, 2011. 